\title{
THE CORPORATE AGENT IN CRIMINAL LAW - AN ARGUMENT FOR COMPREHENSIVE IDENTIFICATION
}

\author{
MARK DSOUZA*
}

The doctrine of identification is often used to explain how corporations can commit criminal offences in their own right. Courts identify the natural persons who can be said to personify the corporation, and attribute their conduct and mental states to the corporation. However, current versions of the doctrine of identification suffer from several well-documented shortcomings. This paper sets out, and gives serious consideration to, a reformulated version of the identification doctrine that has the potential to addresses many of these shortcomings.

In Section I, I explain how the doctrine of identification promotes the sociological legitimacy of corporate criminal law by allowing it to piggyback on the sociological legitimacy of the criminal law as it applies to natural persons. Next, in Section II, I describe the existing versions of the doctrine of identification, and the problems with them. In Section III, I argue that because the various alternatives to the identification doctrine might tend to undermine the sociological legitimacy of corporate criminal law, a suitably reformulated rule of identification would be preferable to abandoning identification altogether. Section IV describes such a reformulation, viz. comprehensive identification (CI). CI would attribute to corporations both the actions, and the mental states, of each of its employees acting in the course of their employment, that is to say, within the scope of their real or ostensible authority. While it would vastly expand the scope of corporate criminal liability, I demonstrate that it would also correct or ameliorate many of the problems that existing versions of the identification doctrine generate. I explain why the policy arguments against such an expansion of corporate criminal liability fail to convince, especially when juxtaposed with the criminal law's response to similar arguments made on behalf of natural persons. Finally, in Section V, I identify the key conclusions of this paper. I argue that CI's approach to theorising corporate criminal liability is promising and worthy of further study and analysis. At any rate, it exposes some of the

\footnotetext{
* I am grateful for the research support provided by Ms Mercedes Hering. Drafts of this paper were presented at various seminars and I am grateful for the insightful comments, suggestions and criticisms of the each of the attendees. In particular, I am grateful for the detailed feedback provided by Brandon Garrett, Samuel Buell, Will Thomas, Mihailis Diamantis, Doug Husak, Amy Sepinwall, Malcolm Thorburn, Francois Tanguay-Renaud, Vincent Chiao, Findlay Stark, Prince Saprai, Kevin Toh, George Letsas, Hasan Dindjer, Maytal Gilboa, Kristen Bell, Sinéad Agnew, Paul Davies, Sina Akbari, and the anonymous reviewers.
} 
weaknesses in arguments commonly deployed to limit corporate criminal liability. Additionally, in highlighting the harshness with which the criminal law treats natural persons, it also gives us good reason to press for moderation across the board in the criminal law.

\section{IDENTIFICATION AND CORPORATE CRIMINAL LAW's SOCIOLOGICAL LEGITIMACY}

Whilst I am unsure that we must necessarily apply the criminal law to companies, intuitively, one attraction of doing so seems to be the criminal law's ability to provide one thing that no other domain of law can: a conviction. As Lamond explains,

[a] successful prosecution does not simply result in a defendant being held liable for the breach of a legal prohibition - instead she is convicted of committing a crime — she is found guilty of the charge against her. These are socially expressive terms. The criminal law serves an important condemnatory function in social life - it marks out some behaviour as especially reprehensible, so that the machinery of the state needs to be mobilized against it. ${ }^{1}$

A conviction publicly condemns the defendant. It has a communicative function that civil judgments do not - publicly recognising and labelling the defendant as a criminal, with all the resonance and social meaning of the term. ${ }^{2}$ This communication about the defendant is addressed to both, the defendant, and the general public. ${ }^{3}$

It is especially the second part of this communicative function that seems to motivate legal systems' insistence on corporate criminal law. A corporate conviction communicates to the public that the criminal justice system takes the corporation's conduct (postponing for the moment, controversy about which conduct is the corporation) extremely seriously. So seriously in fact, that it labels the conduct as criminal, with all the expressive content of that term. Most, if not all, other negative aspects of a conviction can be replicated (often more effectively) in

G. Lamond, "What is a Crime?" (2007) 27 O.J.L.S. 609, 610.

2 A.P. Simester, J.R. Spencer, F. Stark, G.R. Sullivan and G.J. Virgo, Simester and Sullivan's Criminal Law: Theory and Doctrine, 7th ed. (Oxford 2019), 5; S.E. Marshall and R.A. Duff, "Criminalization and Sharing Wrongs" (1998) 11 Can.J.L.\& Juris. 7.

3 J. Hampton, "The Moral Education Theory of Punishment" (1984) 13 Philosophy \& Public Affairs 208, 212; S. Buell, "The Blaming Function of Entity Criminal Liability” (2006) 81 Ind. L.J. 473, 503. 
tort proceedings. But only a criminal conviction communicates to the public the law's judgment that the corporation's conduct was so bad that the layperson would recognise it as "criminal". 4

This recognition is important because the communication here is a two-way street. A significant body of academic opinion notes that the law trades on its sociological legitimacy, which depends, inter alia, on the law operating in a manner that is generally seen to be consonant with norms, values, beliefs, practices and procedures that individuals presume are widely shared, whether or not they personally share them. ${ }^{5}$ If the layperson recognises a convicted corporation's conduct as criminal (by reference to the relevant norms, values, beliefs, practices and procedures that are presumed to be widely shared), this enhances the sociological legitimacy of the law that generates the conviction, thereby (the theory goes) boosting its acceptance and effectiveness. Conversely, where the convicted corporation's conduct is not so recognised as criminal, or more commonly, where corporate conduct that the layperson does recognise as criminal is systematically exempted from criminal convictions, the corporate criminal law's sociological legitimacy suffers.

I cannot mount a sustained defence of this suggestion here, but if it is correct, it has implications for how corporate criminal law ought to be structured. A good corporate criminal law would regularly generate corporate convictions that the layperson would recognise as being consonant with the relevant norms, values, beliefs, practices and procedures presumed to be widely shared. Since the layperson's conception of what sort of behaviour is criminal is

4 Buell, "Entity Criminal Liability", pp. 491, 497-98, 501-07, 524; M. Diamantis, "Corporate Criminal Minds" (2016) 91 Notre Dame L. Rev. 2049, 2063-64; J. Gobert, "Corporate Criminality: New Crimes for the Times" [1994] Crim. L.R. 722, 726-27; Anon., "Regulating Corporate Behaviour through Criminal Sanctions” (1979) 92 Harv. L. Rev. 1227, 1301, 1305. My view does not entail a commitment to a particular theory of punishment any theory of punishment will either require, or be predicated on establishing, a conviction. See P. Pettit, "Responsibility Incorporated" (2007) 117 Ethics 171, 175-76.

5 M. Zelditch Jr., "Theories of Legitimacy" in J. Jost and B. Major (eds.), The Psychology of Legitimacy: Emerging Perspectives on Ideology, Justice, and Intergroup Relations (Cambridge 2001), 39-48; C. Johnson, T.J. Dowd and C.L. Ridgeway, "Legitimacy as a Social Process” (2006) 32 Annual Review of Sociology 53, 55-60; H. Walker, "Beyond Power and Domination: Legitimacy and Formal Organizations" in C. Johnson (ed.), Legitimacy Processes in Organizations (Amsterdam 2004), 253-54. See also M.L. Wells, “'Sociological Legitimacy’ in Supreme Court Opinions” (2007) 64 Wash.\& Lee L.Rev. 1011, 1015, 1027-47 (discussing how judicial law must be sensitive to the public's recognition and acceptance of its rules in order to gain legitimacy). For similar arguments in the context of corporate criminal law see D.M. Kahan, "Social Meaning and the Economic Analysis of Crime” (1998) 27 J.L.S. 609, 618-621; and Buell, “Entity Criminal Liability”, pp. 519-20. 
probably shaped by a rough and ready understanding of the criminal law as applicable to natural persons, that is the layperson's perceived paradigm of criminal law. The criminal law, as applicable to natural persons, has been subject to sustained and rigorous examination by courts and academics over the history of the development of the criminal law. Even if it is not perfect, in settled modern states, it has nevertheless acquired sociological legitimacy. A model of corporate criminal law designed to generate liability outcomes the layperson would recognise as criminal would therefore accord closely with the substantive and procedural norms, values, beliefs, practices and procedures in this paradigm of criminal liability. It would (ordinarily) subject natural and corporate persons to the same broad standards. ${ }^{6}$ On generally accepted parameters, doing so would significantly enhance the corporate criminal law's sociological legitimacy. It is therefore worth exploring what a criminal law that (ordinarily) subjected natural persons and corporations to the same standards would look like.

If the criminal law applied similarly to natural and corporate persons, we would expect criminal liability for both to be established in essentially the same way, with essentially the same rules and labels applying. Thus, a defendant (human or corporate) shown to have performed the actus reus of the offence with the mens rea for it, would, subject to applicable defences, be convicted of an offence that carries a recognisable and appropriate label. And indeed, the traditional approach to corporate criminal liability does try to fit corporations into that paradigm. It tries to identify the natural person(s) who can be said to personify the corporation, such that their acts and states of mind may be attributed to the corporation for the purposes of determining criminal liability. ${ }^{7}$ This is called the doctrine of identification, and despite its many problems, it endures.

One may counter that since corporations and persons are different, different standards should apply. But a characteristic feature of corporate criminal liability is that it "imitate[s] the imposition of criminal liability on human beings". E. Lederman, "Models for Imposing Corporate Criminal Liability" (2000) 4 Buff. Crim. L. Rev. 641, 650-55. See also C. Wells, "The Decline and Rise of English Murder: Corporate Crime and Individual Responsibility" [1988] Crim. L.R. 788, 789-96; C. Wells, "Corporations: Culture, Risk and Criminal Liability" [1993] Crim. L.R. 551, 553; J. Braithwaite, "White Collar Crime” (1985) 11 Annual Review of Sociology 1, 1314. The label "criminal" carries prior significance; diluting it to apply it to corporations undermines its extension to corporations. Traditionally too, the English law approach has been to analogise corporations to natural persons, rather than to emphasise their differences.

7 Lennard's Carrying Co v Asiatic Petroleum Co [1915] A.C. 705; DPP v Kent and Sussex Contractors [1944] K.B. 146; R. v ICR Haulage [1944] K.B. 551; Moore v I Bresler [1944] 2 All E.R. 515; HL Bolton (Engineering) Co v TJ Graham \& Sons [1957] 1 Q.B. 159; Tesco Supermarkets v Nattrass [1972] A.C. 153; R. v Redfern and Dunlop 
The recent trend in English corporate criminal law however, is different. Increasingly, English criminal law tries to sidestep the complications of needing to attribute conduct and mental states to corporations. It creates statutory offences which allow a company to be convicted for identified omissions, even without mens rea; ${ }^{8}$ it criminalises the company's failure to prevent the criminal acts of persons associated with it, and offers a defence to companies that had in place appropriate measures to prevent such criminality ${ }^{9}$ it imposes liability on the company based on how its activities are managed or organised by senior management; ${ }^{10}$ or it just holds the company vicariously liable for its employees' offences. ${ }^{11}$ These options, when available, make prosecution easier, and this method of developing corporate criminal law has found academic support. ${ }^{12}$

But there are at least two major general problems with this approach to corporate criminality. ${ }^{13}$ Firstly, bespoke corporate offences that are used to sidestep questions of attribution also carry bespoke labels. As these labels differ from those applicable to the same wrongdoing perpetrated by a human, they tend to be less familiar, and may obfuscate the seriousness of the corporate wrongdoing. This raises concerns about fair-labelling of the

(1992) 13 Cr. App. R. (S.) 709; Meridian Global Funds Management Asia v Securities Commission [1995] 2 A.C. 500; Attorney-General's Reference (No.2 of 1999) [2000] Q.B. 796; R. v St Regis Paper Co [2011] EWCA Crim 2527, [2012] 1 Cr. App. R. 14.

8 E.g., Health and Safety at Work etc. Act 1974, s. 33(1)(a).

9 E.g., Bribery Act 2010, s. 7.

10 E.g., Corporate Manslaughter and Corporate Homicide Act 2007, s. 1.

11 Tesco Stores v Brent LBC [1993] 1 W.L.R. 1037; DGFT v Pioneer Concrete (UK) [1995] 1 A.C. 456; R. v HM Coroner for East Kent, ex p Spooner (1989) 88 Cr. App. R. 10, 16; Law Commission, Criminal Liability in Regulatory Contexts (Law. Com. C.P. No. 195, 2010), para. 5.16; and Law Commission, Involuntary Manslaughter (Law. Com. No. 237, 1996). See also the offence of "Failure of commercial organisation to prevent bribery", Bribery Act 2010, s. 7. cf. G.R. Sullivan, "The Attribution of Culpability to Limited Companies" (1996) 55 C.L.J. 515, 518, who argues that identification is a restricted version of vicarious liability, since it is triggered by findings of culpability only in respect of a narrow class of senior officials. The suggestion that identification is not conceptually distinct from vicarious liability runs contrary to dicta in Nattrass [1972] A.C. 153, 170, 179, 190.

12 See for instance, C. Wells, "Corporate Failure to Prevent Economic Crime - a Proposal" [2017] Crim. L.R. 423; L. Campbell, "Corporate Liability and the Criminalisation of Failure" (2018) 12 L.F.M.R. 57. cf. A. Ashworth, "A New Generation of Omissions Offences" [2018] Crim. L.R. 354, 362-65.

13 Several other narrower objections are surveyed in Ashworth, "Omissions Offences". 
wrongdoing and offender, ${ }^{14}$ and, insofar as the choice of applicable label does not track societal expectations presumed to be widely shared, arguably undermines the law's sociological legitimacy. Secondly, such patchwork corporate criminalisation inevitably leaves gaps and so we still need a safety net to avert corporate impunity. Therefore, the traditional strategy of devising rules of attribution that allow us to apply the same criminal law to natural and corporate persons remains important. But current versions of the doctrine of identification are sub-optimal ways of giving effect to this strategy.

\section{THREE (EXISTING) VERSIONS OF IDENTIFICATION}

The first problem with applying the criminal law (as applicable to natural persons) to corporations, is figuring out who the company is. This question is separate from, and logically prior to, questions of corporate culpability - we cannot evaluate a company's culpability without first having a plausible conception of the company's ontology. Only once we know who the company is, can we consider attributing conduct and mental states to it, and evaluating its culpability.

English criminal law addresses the ontology of the company using the doctrine of identification. It likens a company to a natural person; so much so, that it tries to find natural persons who personify the company. Under the doctrine of identification, if these persons perform the criminal conduct with a culpable mental state, then so does the company. ${ }^{15}$ Usually, the natural persons pinpointed are those "who [are] really the directing mind and will of the corporation, the very ego and centre of the personality of the corporation". ${ }^{16}$ This anthropomorphic conception of a company was explained thus by Lord Reid in Tesco $v$ Nattrass:

14 On fair labelling generally see A. Ashworth, Principles of Criminal Law, 6th ed. (Oxford 2009), 78; A.P. Simester and G.R. Sullivan, “On the Nature and Rationale of Property Offences” in R.A. Duff and S.P. Green (eds.) Defining Crimes (Oxford 2005), 186-87; C. Wells, "Corporate Crime: Opening the Eyes of the Sentry" (2010) 30 L.S. 370, 373-74.

15 The criminal law does not address this question at a metaphysical level, with good reason. The metaphysics of a company would depend, at a minimum, on the concerned company's nature, and the nature of the conduct and mental state being considered for attribution. Such inquiry is therefore ill-equipped to generate the sort of precise rule that can serve the interests of either business (which relies on certainty to manage risk) or the criminal law (which relies on it for fair warning).

16 Lennard's [1915] A.C. 705, 713. 
A corporation... must act through living persons, though not always one or the same person... the person who acts is not speaking or acting for the company. He is acting as the company and his mind which directs his acts is the mind of the company. There is no question of the company being vicariously liable. He is not acting as a servant, representative, agent or delegate. He is an embodiment of the company or, one could say, he hears and speaks through the persona of the company, within his appropriate sphere, and his mind is the mind of the company. If it is a guilty mind then that guilt is the guilt of the company. ${ }^{17}$

This device then, allows us to apply familiar criminal law offences and rules to companies, ${ }^{18}$ thereby generating convictions that laypersons can easily recognise as properly criminal. However, identification has its problems.

Different courts (and sometimes, different judges in the same court) differ as to whether the persons who think as the company, also act as the company. So, for instance, Denning LJ in HL Bolton (Engineering) Co v TJ Graham \& Sons, suggested that different people may be tasked with acting for the company and thinking for it:

A company may... be likened to a human body. It has a brain and nerve centre which controls what it does. It also has hands which hold the tools and act in accordance with directions from the centre. Some of the people in the company are mere servants and agents who are nothing more than hands to do the work and cannot be said to represent the mind or will. Others are directors and managers who represent the directing mind and will of the company, and control what it does. The state of mind of these managers is the state of mind of the company and is treated by the law as such. ${ }^{19}$

I call this first version of identification split identification. By contrast, Lord Reid, in Nattrass (quoted above) favoured what I call unified identification - the notion that the same persons both act, and think, as the company. ${ }^{20}$

Decades later, the Privy Council in Meridian Global Funds Management tried to limit the Nattrass ruling, by proposing a third version of identification. It opined that Nattrass did not set out a one-size-fits-all test of identification (whether split or unified). Instead, said the Privy Council, the House of Lords in Nattrass set out a rule adapted to the statutory context of the

17 Nattrass [1972] A.C. 153, 170. See also Kent \& Sussex [1944] K.B. 146, 155-157.

18 Lederman, “Corporate Criminal Liability”, pp. 651, 655-56.

19 Bolton [1957] 1 Q.B. 159, 172. See also Pioneer [1995] 1 A.C. 456, 468, 475.

20 Nattrass [1972] A.C. 153, 170. See also Kent \& Sussex [1944] K.B. 146, 156; ICR Haulage [1944] K.B. 551, 559; Moore [1944] 2 All E.R. 515, 516-18; R. v P\&O Ferries (Dover) [1991] 93 Cr. App. R. 72, 82. 
facts before it. On the Privy Council's view, whenever the law imposes corporate criminal liability, the identification of the officers who personify the corporation is a matter of construction, keeping in mind the words of the statute (if any) and the context of the provision. ${ }^{21}$ While this disjunctive view of identification seemed to substantially shake up the identification doctrine, the Privy Council's invitation to find, in the broader context of a rule, guidance expanding the set of officers who personify the corporation, has rarely been accepted. ${ }^{22}$ Even so, the Law Commission endorsed disjunctive identification, ${ }^{23}$ because it facilitated the application of the criminal law to corporations when appropriate. It recommended that this approach be supplemented by allowing "courts... to apply a defence of due diligence... to a statutory provision imposing criminal liability without a requirement for... fault... [T]he burden of proof would be on the defendant to show that he or she exercised due diligence in all the circumstances to avoid committing the offence". ${ }^{24}$

\section{A. Theoretical Concerns}

Split identification is plagued with theoretical problems. Lord Denning's vision of the corporate person is based on a classical dualist view of personality, which posits the existence in one person of two distinct elements: a physical body, which occupies and moves in space, and a nonphysical mind, which thinks and feels. ${ }^{25}$ Accordingly, different people act, and think, for the company. This mind-body duality is doubted, even for natural persons. ${ }^{26}$ At any rate, it is controversial enough to be a dubious basis for analogy. But even on a dualist view of personality, it seems strange to have different rules for identifying the company depending on whether we are attributing acts or mental states to it. ${ }^{27}$ That is not the criminal law's general approach in respect of natural persons, and the disanalogy is particularly jarring in a theory of corporate criminal liability built on the analogy with natural persons. Yet often the actions, but

21 Meridian [1995] 2 A.C. 500, 507.

22 See for instance A-G's Reference [2000] Q.B. 796; St Regis Paper [2011] EWCA Crim 2527, [2012] 1 Cr. App. R. 14.

23 Law. Com. C.P. No. 195, para. 5.103.

24 Ibid., para. 6.1.

25 R.A. Duff, Intention, Agency and Criminal Liability (Oxford 1990), 116; R. Descartes, Meditations on First Philosophy, Eng. tr. (Cambridge 1986).

26 Duff, Intention, Agency and Criminal Liability, pp. 116-35; C. Wells, Corporations and Criminal Liability, 2nd ed. (Oxford 2001), 71.

27 R. Mays, "Towards Corporate Fault as the Basis of Criminal Liability of Corporations" (1998) M.J.L.S. 31, 42. 
not mental states, of employees acting in the course of corporate employment, are attributed to corporations. ${ }^{28}$ Accordingly, courts regularly impose on companies, strict criminal liability, ${ }^{29}$ or liability for failing to properly perform statutory duties. ${ }^{30}$ At the cost of principled legal argumentation then, split identification lets courts impose corporate criminal liability in appropriate cases: the narrowness of the rule on attributing mental states poses no difficulty. ${ }^{31}$ Yet, expedience alone cannot supply a convincing principled argument for splitting identification in this way.

At the cost of narrowing the scope for strict corporate criminal liability, unified identification avoids this concern, by using the same rule of attribution for acts and mental states. However, there remains significant uncertainty about what exactly this rule is. Even in Nattrass, the locus classicus for unified identification, the Lords' speeches contained at least three different candidate rules, each generating different enumerations of the corporate officers embodying the company. ${ }^{32}$ There is little explanation in any of these rules about why, in principle, certain officials are identified with the company, whereas others are not.

While the House of Lords in Nattrass offered no deep principled explanation of its conclusions, the Privy Council's suggestion of disjunctive identification in Meridian is expressly premised on deep principled explanations being impossible. ${ }^{33}$ The Law Commission plumped for disjunctive identification, but undermined its position by blithely suggesting that when corporations relied on its proposed due diligence defence to strict liability offences,

28 For instance, Pioneer [1995] 1 A.C. 456, 465, 470-81; R. v Great North of England Rly Co (1846) 9 Q.B. 315; Bolton [1957] 1 Q.B. 159; P\&O Ferries [1991] 93 Cr. App. R. 72, 83-84; Mousell Bros v London and NorthWestern Railway Co [1917] 2 K.B. 836, 845; Griffiths v Studebakers [1924] 1 K.B. 102, 105.

29 D. Ormerod and K. Laird, Smith, Hogan and Ormerod's Criminal Law, 15th ed. (Oxford 2018), 248-49, 271-72; Griffiths [1924] 1 K.B. 102.

30 Mousell [1917] 2 K.B. 836; Great North of England (1846) 9 Q.B. 315; Bolton [1957] 1 Q.B. 159.

31 Simester et.al., Simester and Sullivan, pp. 296-97.

32 Nattrass [1972] A.C. 153. Lord Reid (171) identified "the board of directors, the managing director and perhaps other superior officers of a company". Viscount Dilhorne (187-88) held that one had "to determine... who are... in actual control of the operations of the company". He considered that these would include "any director, manager, secretary or other similar officer of the body corporate or any person... purporting to act in any such capacity". Lord Pearson (193) added, and Lord Diplock agreed (199-200), that one should also refer to the company's constitutional documents in making this determination.

33 The Privy Council described attribution to corporations as a "question... of construction rather than metaphysics". Meridian [1995] 2 A.C. 500, 511. 
reference should be made to "the due diligence of directors (or equivalent persons)". ${ }^{34}$ Effectively, it employed the same Nattrass style generalisation as to which officers could be identified with the company, that it was recommending against.

But principled argumentation about the identification doctrine is possible. We could, for instance, argue that since the identification doctrine is expressly based on analogy with natural persons, that analogy should apply unless excluded. By that yardstick, disjunctive identification is bizarre - the nature of the offence does not dictate the rule of attribution for natural persons, so why should it for corporate persons? $?^{35}$ The Nattrass models too seem incongruous. Natural persons do not get to say, "It was my foot, not me!", so why should we let companies disclaim responsibility by saying, "It was my sales manager, not me"? ${ }^{36}$

Admittedly, these objections are hardly conclusive - they just raise doubts about the principled appositeness of the leading models of identification. However, the House of Lords in Nattrass also offered a doctrinal argument for its conclusions. If, pace the Privy Council in Meridian, Nattrass does set out a general rule on identification, then that argument also bears evaluating.

\section{B. Doctrinal Concerns}

In Nattrass, a Tesco store manager's error resulted in washing powder being sold for more than the advertised price. Tesco Supermarkets was charged with an offence under s. 11(2) of the Trade Descriptions Act 1968. ${ }^{37}$ The prosecutor asserted, and Tesco did not dispute, that Tesco (through its local employees) had indicated "that the goods were offered at a price less than that at which they were in fact being offered". Apparently, a broad notion of vicarious

34 Law. Com. C.P. No. 195, para. 6.21.

35 Ormerod and Laird, Smith, Hogan, p. 251 agree that " $[\mathrm{t}]$ he test... [of identification must be] the same whether the offence be serious or trivial."

36 One answer may be that the dualistic distinction between mind and body is more useful when thinking about corporations. The truth of this proposition depends on whether dualistic ontological models of corporations generate better consequences (however we flesh out that yardstick) than non-dualistic ones. In Section IV, I will propose a non-dualistic ontological model of corporations, and argue that it generates superior outcomes. My thanks to Findlay Stark for pressing me on this point.

37 This provision made it an offence for "any person offering to supply any goods [to give]... any indication... that the goods are being offered at a price less than that at which they are in fact being offered". 
responsibility for the acts of employees was assumed to apply to giving the indication. Tesco did however, rely on s. 24(1) of the Act, under which it is,

...a defence for the person charged to prove (a) that the commission of the offence was due to... the act or default of another person... and (b) that he took all reasonable precautions and exercised all due diligence to avoid the commission of such an offence by himself or any person under his control.

Tesco argued that the offence was due to the default of its store manager, who was, vis-àvis Tesco, "another person", and that it had exercised all due diligence to avoid the commission of the offence by itself or people under its control. In agreeing that the store manager was, visà-vis Tesco, "another person", the House of Lords relied partly on s. 20 of the Act, and partly on its own ruling in Lennard's.

To the extent that the Lords relied on s. 20, the logical flaws are striking. s. 20(1) reads:

Where an offence... which has been committed by a body corporate is proved to have been committed with the consent and connivance of, or to be attributable to any neglect on the part of, any director, manager, secretary or other similar officer of the body corporate, or any person who was purporting to act in any such capacity, he as well as the body corporate shall be guilty of that offence and shall be liable to be proceeded against and punished accordingly.

This section does not relate to the defence in s. 24. However, for the House of Lords:

The natural persons described in [s. 20(1)] correspond with those who under the memorandum and articles of association of a company exercise the powers of the company itself. From this it follows that if any of them is guilty of neglect in the exercise of those powers such neglect is that of the company itself. That it cannot be relied upon as "the act or default of another person", so as to entitle the company to a defence under section 24(1), is implicit in the provision in section 20(1) that a person in the described category shall be guilty of an offence "as well as the body corporate". Without section 20 it would have been open to doubt whether persons whose acts were in law the acts of the company itself would have been guilty in their personal capacity also of the offence committed by the company. ${ }^{38}$ [Emphasis added]

The logical proposition in the emphasised text above is simply incorrect. Assume for the sake of argument that "those who under the memorandum and articles of association... exercise the powers of the company itself" may bring criminal liability upon the company by their acts.

38 Nattrass [1972] A.C. 153, 201. 
Nothing in the Act (or elsewhere) suggests that by doing so, such persons would simultaneously immunise themselves against criminal liability for the same acts. Multiple people are regularly held liable for the same offence, whether as multiple principals, or as principals and accessories. True, in the absence of s. 20, the named persons might not have been liable to a personal conviction, but only because they might neither commit the prima facie offence as principals, nor qualify as accessories under the standard rules of accessorial liability. Therefore, s. 20 makes the named natural persons personally liable based merely on their consent to, connivance in, or negligence in contributing to, the corporation's commission of the offence. This basis for liability is wider than accessorial liability under s. 8 of the Accessories and Abettors Act 1861, or liability as a joint principal. But the inclusion of certain natural persons in the list in s. 20 in no way suggests that only they personify the corporation.

Separately, the House of Lords in Nattrass purported to draw support for its conclusions from Lennard's. However, the Privy Council in Meridian ruled that this was an error - it held that Lennard's was not setting out a general rule about which corporate officers could be identified with a company. Instead, its ruling was limited to the specific statutory provision applicable therein. In that limited context, Mr Lennard, who was characterised as the "directing mind and will" of the company, was held to personify the company. ${ }^{39}$

Accordingly, Nattrass seems to offer no convincing reason to draw the line at any of the levels suggested in its various judgments when identifying the "self" of a company.

\section{Arguments from Consequences}

Another way of defending these rules of identification is by reference to the likely downstream economic consequences of using broader or narrower rules. ${ }^{40} \mathrm{We}$ should view this approach with caution. Identifying the defendant-agent is only the first step in applying the criminal law. A plethora of other factors also influence liability outcomes and economic consequences, and so judging the desirability of models of identification based on downstream economic consequences is risky. ${ }^{41}$ Moreover, rarely is the criminal law conceived of in terms so

39 Meridian [1995] 2 A.C. 500, 509-10.

40 See for instance, Simester et.al., Simester and Sullivan, pp. 297-98; Ormerod and Laird, Smith, Hogan, pp. 26162; Meridian [1995] 2 A.C. 500.

${ }^{41}$ Except when a model of identification rules out liability. But rarely are downstream-consequence-based arguments limited to such cases. 
thoroughgoingly consequentialist that the (downstream economic) ends not only justify the means, but also dictate how we identify the defendant.

Even if, miraculously, we all agreed on the appropriate ends of the criminal law, arguments like this rely on predictions about counterfactual economic consequences that might flow from using alternative rules of identification. These predictions are rarely verifiable, and so amount to little more than educated guesswork. They offer no knockdown reason to prefer one rule over another - at most, their appeal to our educated hopes and fears about the consequences of adopting alternative rules is weakly persuasive.

We are much more certain that existing versions of the identification doctrine generate consequences that often make us uneasy.

For one, the dissonance between the various different models of identification proposed in various judgments makes the content of the law uncertain and its application unpredictable. ${ }^{42}$ The Meridian ruling compounds these problems by suggesting that there is no general test for identification, and that the test applicable for a particular offence depends on the context and underlying policy motivating that offence. While this mode of statutory construction is hardly novel, its use in respect of companies and in the criminal law context is worrying. Businesses abhor uncertainty, and there is an especial imperative for certainty, predictability, and fair warning in the criminal law. This disjunctive approach to identification would leave the rules governing a company's liability for a particular type of criminal offence in a very unsettled and uncertain state, ${ }^{43}$ for both existing criminal offences, and for new offences with no definitive list of the persons who may make a company liable. In any event, the tepid judicial response to the Meridian ruling has meant that while it remains possible that a court will use the Meridian approach to attribution, it is more likely (but hardly certain) to apply a more familiar (and narrow) rule deriving from Nattrass. Effectively, Meridian has exacerbated the uncertainty problem by introducing an additional layer of unpredictability as to the content of the rules of criminal attribution.

Even assuming that the Nattrass conception of the identification doctrine remains predominant, problems persist. For one, each version of the Nattrass identification doctrines

42 Ormerod and Laird, Smith, Hogan, p. 250. See also Mays, "Towards Corporate Fault", p. 44.

${ }^{43}$ Law. Com. C.P. No. 195, paras. 5.78-5.79, 5.104; Sullivan, "Attribution of Culpability", p. 521; Ormerod and Laird, Smith, Hogan, pp. 251-52. 
generates a very narrow domain of corporate criminal liability. Under any of them, it would be rare, especially for large corporations, to be criminally liable, even for very serious wrongdoings. Rarely would a sufficiently senior corporate officer be sufficiently culpable. ${ }^{44}$ So for instance, the ship's master was to blame for the Zeebrugge disaster, but he was not considered senior enough to be identified with the ship-owning corporation. ${ }^{45}$ Similarly, in Redfern, ${ }^{46}$ a corporation's European Sales Manager did not make it liable for embargoviolating sales to Iran that he authorised. Even the ruling in Meridian did not disrupt the trend. In A-G's Reference (No.2 of 1999), ${ }^{47}$ the Court of Appeal insisted that the identification doctrine had survived Meridian, and so applied a version of the Nattrass rule. Likewise, in $S t$ Regis Paper $\mathrm{Co}^{48}$ the Court of Appeal used Meridian's flexible approach to reach a wholly traditional conclusion: refusing to identify a corporation with its technical manager, even in relation to tasks that were entirely for him to perform. By these judgments, the Court of Appeal approved the acquittals of corporations in relation to a serious and easily avoidable train accident, and deliberate environmental pollution and the concealment thereof. These decisions have led to unease amongst the public at the significant immunity from criminal prosecution that being incorporated seems to grant businesses. The public opinion, with some justification, was that the concerned corporations had engaged in reprehensible, badly motivated, or lax behaviour, deserving of criminal sanction, but the state of the law made criminal sanction impossible. ${ }^{49}$ The dissatisfaction seems to relate to English law's approach to corporate criminal liability, insofar as it applies completely different sets of rules to defendants who bring about the same harm depending on whether they are incorporated. This sort of dissonance undermines the sociological legitimacy of English corporate criminal law.

Occasionally, some junior corporate functionary can be convicted even when the company itself is not. But this hardly suffices. Frequently, it is the corporation, not the junior functionary,

44 Ormerod and Laird, Smith, Hogan, p. 250; Simester et.al., Simester and Sullivan, p. 295; J. Gobert, "Corporate Criminality: Four Models of Fault" (1994) 14 L.S. 393, 400-01.

45 P\&O Ferries [1991] 93 Cr. App. R. 72; See also Simester et.al., Simester and Sullivan, p. 296; Wells, Corporations and Criminal Liability, pp. 48-50.

46 Redfern (1992) 13 Cr. App. R. (S.) 709.

47 A-G's Reference [2000] Q.B. 796.

48 [2011] EWCA Crim 2527, [2012] 1 Cr. App. R. 14.

49 Ormerod and Laird, Smith, Hogan, p. 246; M. Jefferson, "Review of P. Almond's Corporate Manslaughter and Regulatory Reform" [2014] Crim. L.R. 162, 163-64; C. Wells, "Corporate Criminal Liability: A Ten Year Review" [2014] Crim. L.R. 849, 853. 
that is seen as the "true" criminal. In Nattrass for instance, it would be surprising if the public imagination was that the store manager, John Clement, had cheated customers. Members of the public were not going to Clement to buy their groceries and supplies. They were going to Tesco. And the profits from the sales overseen by Clement went not (in the most part) to him, but to Tesco. ${ }^{50}$ Therefore it is more likely that Tesco was seen as the responsible party. As Lord Denman pointedly noted in $R . v$ Great North of England Rly:

We are told that... the individuals who concur in voting the order, or in executing the work, may be made answerable for it by criminal proceedings. Of this there is no doubt. But the public knows nothing of the former; and the latter, if they can be identified, are commonly persons of the lowest rank, wholly incompetent to make any reparation for the injury. ${ }^{51}$

A criminal law that fails to assign labels that (at least broadly) correspond to public perceptions lacks sociological legitimacy and public credibility, ${ }^{52}$ which are amongst its main tools for guiding and modifying public behaviour. Current identification rules seem incapable of generating labels that reflect public perceptions in most cases.

Two connected concerns arise from the fact that these rules are more likely to convict corporations in which the senior management is directly involved in day-to-day public-facing activities. Firstly, these rules unfairly prejudice small companies vis-à-vis large ones, because the mere size of the latter seems to immunise them against criminal consequences. ${ }^{53}$ Consider Sullivan's example of,

a company which consistently profits by wrongdoing against third parties... [like] an insurance company selling, on a regular basis, pension schemes unsuited to clients' needs. There are indications... that company salespersons may have dishonestly misrepresented the effects of policies, whereas all that has been revealed in terms of corporate policy resolved at senior level is a "hard-sell" bonus-based sales scheme. There would be little chance of a corporate conviction for an offence of dishonesty in such circumstances. ${ }^{54}$

50 See also Buell, "Entity Criminal Liability", pp. 491-93; Wells, Corporations and Criminal Liability, p. 157.

51 Great North of England (1846) 9 Q.B. 315, 326-27.

52 See the discussion accompanying notes 5 and 6 above.

53 Law. Com. C.P. No. 195, paras. 5.87-5.88, J. Gobert and M. Punch, Rethinking Corporate Crime (London 2003), 63; Wells, Corporations and Criminal Liability, p. 157; Mays, “Towards Corporate Fault”, p. 43.

54 Sullivan, “Attribution of Culpability”, p. 519. Wells, Corporations and Criminal Liability, pp. 157-58. 
Secondly, this model of corporate liability offers corporations, large and small, perverse incentives to set up convoluted organisational structures designed to avoid criminal liability. ${ }^{55}$ Such structures introduce organisational inefficiencies, even if they successfully circumvent criminal liability. ${ }^{56}$

All in all, in its present form at least, the doctrine of identification offers little legal certainty, lacks principled foundations, and is based on questionable doctrinal logic. De facto, it creates an alternative (and significantly more lenient) criminal law applicable only to corporations, frequently generates liability outcomes that confound our sense of justice, ${ }^{57}$ unfairly discriminates between corporations based on size and organisational complexity, and arguably incentivises the creation of inefficient organisational structures. In sum, in its present form, the doctrine of identification is unfit for purpose.

\section{ALTERNATIVES TO IDENTIFICATION}

Faced with these objections, it is tempting to abandon the doctrine of identification entirely and adopt a completely different model. One option, used in the United States, is the doctrine of respondeat superior - a form of vicarious liability under which corporations are criminally liable for offences committed by their employees within the scope of employment and with intent to benefit the corporation. ${ }^{58}$ English law however, harbours a strongly entrenched resistance to any general doctrine of vicarious criminal liability stemming from its insistence on personal culpability in the criminal law. ${ }^{59}$ In other words, the concern is that respondeat superior would make an employer corporation liable despite lacking personal culpability, and

55 Law. Com. C.P. No. 195, paras. 5.87-5.88; Gobert and Punch, Rethinking Corporate Crime, p. 63.

56 Braithwaite, "White Collar Crime", p. 17.

57 Gobert, "Four Models", pp. 395, 401; Wells, Corporations and Criminal Liability, pp. 110-113; W. Wilson, Criminal Law, 6th ed. (Cambridge 2017), 172; Simester et.al., Simester and Sullivan, p. 296; Law. Com. C.P. No. 195, paras. 5.84-5.91.

58 N.Y. Cent. \& Hudson River Ry. v United States, 212 U.S. 481 (1909); Lederman, "Corporate Criminal Liability”, pp. 654-55; V.S. Khanna, "Corporate Liability Standards: When Should Corporations Be Held Criminally Liable” (2000) 37 Am. Crim. L. Rev. 1239, 1242-43. In practice, corporations are rarely prosecuted - instead, the credible threat of prosecution encourages corporations to accept fines, compliance oversight, and to assist prosecutions of culpable individual employees. See B.L. Garrett, Too Big to Jail (London 2014), 20-36, ch. 6; S.W. Buell, "Why Do Prosecutors Say Anything? The Case of Corporate Crime”, (2018) 96 N.C.L. Rev. 823, 830-31.

59 R. v Huggins (1730) 93 E.R. 915; R. (Chief Constable of Northumbria Police) v Newcastle Upon Tyne Magistrates' Court [2010] EWHC 935 (Admin); Meridian [1995] 2 A.C. 500, 507; Law. Com. No. 237, paras. 6.8, 7.29. 
that this is oppressive. A connected worry is that if corporate persons could vicariously be criminally liable for offences committed by their employees, then in the absence of any principled objection, we might be tempted to extend this rule to natural persons. ${ }^{60}$ This would greatly extend the net of criminal liability, while simultaneously diluting the difference between civil and criminal liability. While the United States was willing to take this risk, it seems unlikely that English law will follow suit.

Other alternatives to identification that have been suggested include the "reactive fault" and the "organisational" 62 models of corporate criminal liability. Neither has seen significant uptake in English law, ${ }^{63}$ and both call for radical changes in the criminal law's functioning by shifting the traditional locus of the defendant's culpability and detaching it from the actus reus of the offence. ${ }^{64}$ What's more, where both natural and corporate persons can be charged with the same offence, these models would apparently apply only to corporations. Effectively, we would have parallel sets of criminal law regimes, sharing some common features but operating very differently in relation to culpability.

The same situation could also arise in another way: we might create a separate set of criminal offences, applicable exclusively or mostly to corporations, and imposing liability by

60 Lederman, “Corporate Criminal Liability”, p. 705.

61 B. Fisse and J. Braithwaite, Corporations, Crime and Accountability (Cambridge 1993).

62 Wells, Corporations and Criminal Liability.

63 The organisational fault model at least, has found some acceptance in Australian law, where the Criminal Code Act 1995, s. 12 applies a version to federal corporate offences. It was also the proposed basis for the English statutory offence of corporate manslaughter, but the offence ultimately enacted in the Corporate Manslaughter and Corporate Homicide Act 2007 was a confused mixture of the organisational model and the identification doctrine. See Wells, “Ten Year Review”, p. 857.

64 The reactive fault theory locates culpability in a corporation's response to the actus reus of a criminal offence, rather than its performance of it. See Wells, Corporations and Criminal Liability, p. 159; Simester et.al., Simester and Sullivan, pp. 300-01. The organisational model finds culpability (or lack thereof) in whether corporation's general culture directed, encouraged, tolerated or led to noncompliance with the law. Setting aside momentarily worries about isolating something as vague as a corporate "culture", this approach looks for fault in the culture in place independent of the specific act or omission that constituted the actus reus of the charged offence. If no "culpable culture" existed, then there would be no criminal liability even if the actus reus was traceable to a corporate officer's wrongdoing. Simester et.al., Simester and Sullivan, pp. 302-03; Ormerod and Laird, Smith, Hogan, p. 263. 
reference to special rules. We already have examples of these, viz., corporate manslaughter, and various health and safety offences.

While there is no decisive objection to effectively having such a parallel criminal law regime applicable only to companies, I have argued above that this tends to undermine corporate criminal law's sociological legitimacy. Moreover, at least part of why we want to hold corporations criminally responsible relates to a conviction's morally-loaded content. That moral weight comes from how crimes are traditionally conceived of in the public imagination. This imagination is individual-centric, and invokes blaming judgments for damaging acts, performed with culpable states of mind. ${ }^{65}$ Shifting the locus of culpability away from the objectionable conduct weakens the basis for the public and morally loaded condemnation that is the currency of a conviction. We see this in the way that health and safety offences are frequently not viewed with the same seriousness as "proper" criminal offences: ${ }^{66}$ witness the plethora of "health and safety gone mad" headlines in popular tabloids.

If one struggles to recognise a system of penal sanctions as "truly" criminal, then one might also be less willing to associate with its convictions the censure and public stigma of "true" criminal convictions. This would weaken the criminal law's ability to change behaviour, both in corporations, and by association, in natural persons, while simultaneously ratcheting up the threat of seepage between our rules of criminal liability for corporations and humans. These eventualities are best avoided. The identification doctrine has the advantage of relying on a framework more recognisable (in the public imagination) as criminal law "proper", and therefore (should its faults be corrected) we have reason to prefer it over these alternative models. Accordingly, instead of debating the merits of these alternative models, I propose now to consider the plausibility of one possible reformulation of the identification doctrine.

\section{COMPREHENSIVE IDENTIFICATION}

\section{A. The Proposal}

65 Wells, Corporations and Criminal Liability, pp. 8, 65-66.

66 Gobert, "New Crimes", p. 727; Gobert, "Four Models", p. 394; M. Jefferson, "Corporate Criminal Liability in the 1990s" (2000) 64 J. Crim. L. 106, 107. cf. the discussion accompanying notes 5 and 6 above. 
The central features of the (non-exhaustive) ${ }^{67}$ version of identification that I propose for consideration are easily stated. CI would, as a general rule, attribute the conduct and mental states of any employee acting in the course of her corporate employment, to the company. A person acts in the course of her employment when she acts within her employer's real or ostensible authority. ${ }^{68}$ Contract law recognises that an employee acting with such (real or ostensible) authority can bind the employer to third parties in contract, ${ }^{69}$ and tort law recognises that she make her employer vicariously liable, in reliance-based torts, ${ }^{70}$ to third parties with whom she interacts, provided that the third parties relied upon her representation as to authority. CI is a proposal that the criminal law follow suit by treating corporate employees acting in the course of employment - i.e. within their employers' real or ostensible authority as the company itself, thus potentially making the company criminally liable. ${ }^{71}$

In arguing that existing versions of the identification doctrine are unfit for purpose, I had referred to their inability to facilitate criminal liability even where the justified public opinion is that the corporation, and not (only) the employee(s) concerned, has engaged in reprehensible, badly motivated, or lax behaviour, deserving of criminal sanction. For CI to fare better than its competitors, it must therefore be better at delivering corporate convictions arising from the acts of employees, where this is in line with public expectations based on the norms, values, beliefs, practices and procedures that individuals presume are widely shared. The real or ostensible authority rule in contract and tort also attempts to identify such cases, albeit in the context of generating private law obligations. It is therefore a useful test to adapt and incorporate into CI

67 The model proposed is comprehensive only within the domain hitherto covered by other versions of identification, i.e. a company's liability for its employees' acts. Other modes of attribution relevant to corporate agents and owners remain available. So, vicarious liability where presently available, would continue to be available, and incriminating Board or General Meeting resolutions would still be attributed to the company.

68 Armagas v Mundogas [1986] 1 A.C. 717; Lloyd v Grace, Smith \& Co. [1912] A.C. 716; Uxbridge Permanent Benefit Building Society v Pickard [1939] 2 K.B. 248.

69 Pharmed Medicare Private v Univar [2002] EWCA Civ 1569; Racing UKv Doncaster Racecourse [2005] EWCA Civ 999; Computer 2000 Distribution v ICM Computer Solutions [2004] EWCA Civ 1634.

70 Winter v Hockley Mint [2018] EWCA Civ 2480, [2019] 1 W.L.R. 1617; Armagas [1986] 1 A.C. 717.

71 There is some limited precedent for this approach in the domain of corporate criminal liability. The Australian Criminal Code Act 1995, s. 12.2 attributes the conduct of a corporation's employees, agents, or officers, acting within the scope of their actual or apparent scope or authority, to the corporation. The phrase "actual or apparent authority" covers essentially the same ground as "real or ostensible authority" in the proposal for CI. 
for identifying when an employee may justifiably be treated as conducting herself as the company in what [ever] she is doing.

Although CI along these lines seems a radical suggestion, a similarly broad rule has been applied in the context of the Bribery Act $2010,{ }^{72}$ and it is consistent with Lord Templeman's ruling in DGFT v Pioneer Concrete:

... a company, in its capacity as supplier of goods, like any other person in the capacity of taxpayer, landlord or in any other capacity, falls to be judged by its actions and not by its language. An employee who acts for the company within the scope of his employment is the company. Directors may give instructions, top management may exhort, middle management may question and workers may listen attentively. But if a worker makes a defective product or a lower manager accepts or rejects an order, he is the company. ${ }^{73}$

CI differs from vicarious liability in several important ways. Whereas in vicarious liability cases the master's liability substitutes that of the agent, corporate criminal liability does not ipso facto extinguish the direct perpetrator's potential personal liability, ${ }^{74}$ and nor would it do so under CI. Furthermore, vicarious liability relies on an identifiable individual (or individuals acting in concert) committing the entire offence being attributed to the principal. ${ }^{75}$ Therefore, corporations that separate employees likely to perform different parts of a criminal offence, effectively immunise themselves from vicarious criminal liability. ${ }^{76}$ But at least where the offence involves aggregable mental states, I will argue that such corporations could be caught by CI.

From the perspective of the results it generates, CI looks a lot like respondeat superior. However, in respect of a key theoretical matter, it is significantly different. Since respondeat superior is a form of vicarious liability, it encounters the English criminal law's strongly

72 The Bribery Act 2010, s. 8(5) creates a presumption that an employee's actions expose the company to criminal liability. In fact, s. 8(3) goes further, potentially also allowing agents and subsidiaries to make the company criminally liable by their actions. See also C. Wells, “Who's afraid of the Bribery Act 2010?” [2012] J.B.L. 420, 425.

73 Pioneer [1995] 1 A.C. 456, 465. Note that Lord Templeman uses "scope of employment" interchangeably with “course of employment" (e.g. at 472, 474).

74 Wells, Corporations and Criminal Liability, pp. 153-54.

75 Law. Com. No. 237, para. 7.30; Gobert, "Four Models", p. 398; Lederman, "Corporate Criminal Liability", p. 652.

76 Khanna, “Corporate Liability Standards”, p. 1250. 
entrenched principled resistance to vicarious criminal liability. But CI is not a form of vicarious liability. Vicarious liability makes one person (P) liable for the crimes of another (A). For that doctrine to apply, we therefore need to have a good sense of who $\mathrm{P}$ is and who $\mathrm{A}$ is. Accordingly, where $\mathrm{P}$ is a corporation, we need to know who constitutes the corporation. CI is a theory of identification, not liability, and so it addresses this prior question. ${ }^{77}$ If $\mathrm{A}$ is an employee of the corporation acting in the course of employment, then under the CI model I have in mind, A is $\mathrm{P}$. Therefore, $\mathrm{P}$ is not vicariously liable for the crimes of $\mathrm{A}$. $\mathrm{P}$, the company, is liable in a plenary capacity.

This is important, because it means that in holding the corporation criminally liable under CI, we do not undermine English law's commitment to personal culpability as the basis for criminal liability. CI also offers a clear, principled basis for differentiating between the liability of corporate and human employers for the offences of their employees. So, although CI would expand the scope of criminal liability for corporations, it would not give rise to fears about similarly expanded liability for natural persons. It should therefore be more palatable to English criminal lawyers than respondeat superior.

$\mathrm{CI}$ is incompatible with due diligence defences that rely on showing that corporate employees, acting in the course of their employment (i.e., within the scope of their real or ostensible authority), are not the company. So, in Nattrass, under CI, Tesco would be unable to argue that its store manager was "another person". ${ }^{78}$ However, a company acting through external agents rather than employees could still claim defences based on the direct perpetrator of the offence being "another person". Hence, CI would remain broadly compatible with the due diligence defence suggested by the Law Commission. ${ }^{79}$

Companies can limit their liability by limiting the instances in which an employee would be acting within the course of employment. It will rarely, if ever, be within a corporate employee's real authority to commit an offence, and companies could limit most employees'

77 Capuano explains this by distinguishing between theories of corporate agency (i.e. when natural persons act for companies) and of the corporate organism (i.e. when natural persons acts as companies). A. Capuano, "Company Liability and the Case for a Benefit Test in Organic Attribution" (2009) 24 Austl.J.Corp.L. 177.

78 Nattrass [1972] A.C. 153.

79 Law. Com. C.P. No. 195, paras. 6.1-6.96, except that corporate due diligence could not be judged by reference to the due diligence of directors (or equivalent persons). 
ostensible authority by prominently communicating the limits of their corporate authority to those dealing with them. ${ }^{80}$

\section{B. The Benefits}

There are several normative reasons why CI might be as good as, or preferable to, existing versions of the identification doctrine.

First, there are benefits in terms of fair labelling and sociological legitimacy. If we want the public to take the symbolism of a corporate conviction seriously, the conviction should be recognisably criminal, and it should be imposed on a party readily identifiable as a culprit. CI helps with both. As a version of the identification doctrine, CI analogises corporations to natural persons and thereby lets us apply familiar and widely accepted elements of the criminal law's practices and procedures to corporations as well. Therefore, it harnesses the criminal conviction's entrenched symbolism. Moreover, when companies are involved in criminal wrongdoing, the public rarely identifies the storekeeper, ferry's assistant boatswain, railway technician, or train driver as the culprit. Usually, it identifies the supermarket chain, or the ferry or railway company. These are also the culprits identified by CI, even where the individual who acted improperly has since died or left the company. This too, is likely to enhance corporate criminal law's sociological legitimacy.

Second, CI offers significantly greater legal certainty than current versions of identification. A general rule to the effect that all employees acting in the course of their corporate employment are the company would be easy to apply, understand, and predict, for the general public, juries, and corporations.

Third, CI corrects the widely recognised imbalance in the way extant versions of the identification doctrine treat companies of different sizes. Under it, companies of all sizes would be equally liable to criminal consequences flowing from their employees' conduct.

Fourth, CI would remove the disparity between the risks of criminal liability for wrongdoing that individuals and corporations bear. Not all instances of criminal wrongdoing or risk-taking, whether by natural persons or corporations, are detected. Often, the wrongs that

80 For instance, signs at cafés stating that the till operator must offer a receipt, or the order is free, indicate one limit of the employee's authority. Similarly, banks' warnings not to disclose, even to their employees, passwords and PIN codes, communicate the limits of their employees' authority. 
are discovered conceal a plethora of instances of similar wrongdoing or risk-taking. ${ }^{81}$ When such undetected wrongdoing is perpetrated by individuals acting within their real or ostensible corporate authority, it likely benefits the company, at least in terms of oversight-related costs. It is therefore appropriate to hold the company liable when wrongdoing is detected. This sort of moral luck also permeates the lives of natural persons - every driver has had her concentration momentarily slip, and usually, nothing bad results. When it does, the driver bears the responsibility for her ill luck, just as she receives the benefit of her otherwise good luck. There is no reason that companies should be treated any differently, and CI would make that the case.

Fifth, CI would remove perverse incentives for companies to set up convoluted and inefficient organisational structures designed to avoid criminal liability. It might therefore improve efficiency. ${ }^{82}$

Sixth, CI can boost the effectiveness of corporate criminal law in at least four ways. Firstly, it would deliver convictions in cases like the Zeebrugge disaster and the Southall train crash, that cry out for them. Secondly, in less egregious cases, one might think that rather than criminally punishing the offending company, a better use of the state's limited resources would be (inter alia) to ensure that the company reduces the risk of reoffending. In such cases, CI creates a credible threat of criminal liability that can be leveraged to make corporations agree to compliance oversight (in addition to other penalties) in exchange for deferred or nonprosecution. ${ }^{83}$ Thirdly, it offers a clear explanation of why current doctrine permits companies to be convicted of strict liability and regulatory offences perpetrated though low-level

81 For instance, the absence of a safety device and of rules requiring specified officers to check the bow doors were continuing problems on ferries operated by P\&O European Ferries (Dover) and had nearly led to disaster at least five times before the Zeebrugge disaster: Sheen Report on the Formal Investigation regarding the MV Herald of the Free Enterprise (1987), para. 12.5; Wells, Corporations and Criminal Liability, p. 9. Similarly, the railway technician responsible for the Clapham Junction crash had been laying wires incorrectly for years before the accident occurred: Hidden Investigation into the Clapham Junction Railway Accident (1989), paras. 7.17, 7.227.35. Likewise, the train company involved in the Southall crash had likely delayed repairs to faults in the automatic warning system, etc., several times before the fatal crash: The Southall Rail Accident Inquiry Report (2000), para. 7.19. Connectedly, see Sullivan, “Attribution of Culpability”, p. 513 for his example of insurance companies benefitting from "hard-sell" bonus-based schemes that incentivise insurance misselling.

82 Admittedly, this is speculation. Even so, it would address Braithwaite's oft quoted worry about companies appointing "vice-presidents responsible for going to jail". Braithwaite, "White Collar Crime", p. 7.

83 Indeed, this is often how the US corporate criminal law regime works. See note 58 above. 
employees, even when vicarious liability is unavailable because the direct perpetrators themselves commit no offence. ${ }^{84}$ And fourthly, as I explain below, CI is compatible with, and complements, theories of fault aggregation in negligence-based offences.

I had previously suggested that deviations from the norm of applying the same criminal law standards to natural persons and corporations were possible if justified. So for instance, corporations may justifiably be subjected to more strongly deterrent punishments than natural persons, because the standard objections to deterrent arguments are less persuasive when the convict is a corporation. ${ }^{85}$ Similarly, given differences in the human and corporate form, we might be willing to accommodate a theory that permits the aggregation of some types of corporate fault. Thus, if several corporate employees are individually negligent, though no single instance of negligence is grossly negligent, we may be able to aggregate several negligent acts to find gross negligence on the part of the company. ${ }^{86}$ In Attorney-General's Reference (No. 2 of 1999) ${ }^{87}$ however, the Court of Appeal affirmed a refusal to permit negligence aggregation, and accordingly supported the acquittal of a rail company whose employees' repeated negligence caused a serious train crash. This decision is regrettable. ${ }^{88}$ Subsequent developments indicate a change in the law's trajectory. For instance, the Corporate

84 E.g. in Griffiths [1924] 1 K.B. 102; Mousell [1917] 2 K.B. 836; Pioneer [1995] 1 A.C. 456.

85 For instance, concerns about imposing long prison sentences (with the connected hardship and degradation) are irrelevant, and concerns about the unfairness of penalties have less sway when the entity being penalised has voluntarily submitted itself to jurisdictional criminal laws. Wells, Corporations and Criminal Liability, pp. 2021, 31-39; Braithwaite, "White Collar Crime”, p. 16; Sullivan, “Attribution of Culpability”; Gobert, "Four Models", p. 398.

86 Wells, Corporations and Criminal Liability, p. 156; Simester et.al., Simester and Sullivan, pp. 301-02; Ormerod and Laird, Smith, Hogan, pp. 254-55. cf. Sullivan, “Attribution of Culpability”, pp. 527-28, who objects that aggregation would let us find gross negligence in a company without ever encountering anything greater than "simple" negligence in any individual identified with it. This puzzles Sullivan, because he sees attribution as a special case of vicarious liability (p. 518), in which the agent's fault is attributed to the company. But if, as argued above, identification is distinct from vicarious liability, this objection falls. What's more, we uncontroversially aggregate the several venial negligent errors of individuals to find gross negligence (see $R$. v Adomako [1995] 1 A.C. 171, 182).

87 A-G's Reference [2000] Q.B. 796.

88 J.R. Spencer, "Manslaughter: Corporate Liability for Manslaughter - Gross Negligence” [2000] Crim. L.R. 475, 478-79. 
Manslaughter and Corporate Homicide Act 2007 allows individual acts of negligence to be aggregated into gross negligence on the part of a corporation. ${ }^{89}$

Aggregation has its limits. As the Law Commission observes, it

is peculiarly well-suited to liability established on the basis of gross negligence... people can share an intention, or knowledge, in criminal law [but]... only by an act of will or consciously. By way of contrast, in principle, (gross) negligence may be inferred or found by putting together discrete pieces of conduct that are not in that same sense part of a shared consciousness. ${ }^{90}$

The Law Commission notes that while people may consciously share intention or knowledge, aggregation cannot supply these. The reason becomes clear when one recalls that, doctrinally, subjective mens rea states like intention, knowledge, and recklessness locate fault in an agent's advertent attitude to interests protected by the criminal law, as demonstrated by the choices she makes in relation to them. ${ }^{91}$ Thus, the agent is to blame because she chose to do something that would harm protected interests either with the intention of harming those interests, or despite knowing that it would harm those interests, or despite knowing of a risk (which was objectively unreasonable to run) that it would harm those interests. Subject to available defences, the agent's choice to act is blameworthy because it is made in light of her knowledge or beliefs about how her action would or might affect protected interests. ${ }^{92}$ While aggregation lets us piece together disparate bits of information held by different employees to find a corporate awareness of how some action would or might affect protected interests, it does not supply the choice to undertake the action in light of that awareness. By contrast, since objective mens rea states like negligence do not locate fault in the agent's choices, aggregation's failure to supply a pro tanto blameworthy choice is irrelevant.

In sum, aggregation, insofar as it applies to findings of criminal negligence in corporations, is compatible with, and would complement, CI.

89 Law. Com. C.P. No. 195, paras. 5.92-5.96.

90 Ibid., para. 5.93; See also Wells, Corporations and Criminal Liability, p. 156; Jefferson, "Corporate Criminal Liability in the 1990s", pp. 109-10; Lederman, "Corporate Criminal Liability", pp. 688-89.

91 For a fuller explanation of this view, see M Dsouza, "A Philosophically Enriched Exegesis of Criminal Accessorial Liability" (2019) 8 UCL J.L. and J. 1, 11-13.

92 Lederman, "Corporate Criminal Liability", pp. 667-77, especially 668-69; Gobert, "Four Models", pp. 403-07; Mays, "Towards Corporate Fault", pp. 53-59; M. Dsouza, "Criminal Culpability after the Act" (2015) 26 K.L.J. $440,444$. 


\section{Objections}

CI would vastly expand the scope of corporate criminal liability. A familiar set of objections is trotted out whenever an expansion of corporate criminal liability is mooted, many of which could plausibly be pressed against CI. Some such objections are based on the predicted downstream negative economic and social effects of an expansion of corporate criminal liability. Since we cannot reliably verify these predictions, such objections are speculative, and their persuasive value is limited. I suspect that debating the plausibility of such predictions would deteriorate into an unhelpful exercise in intuition-pumping. Instead, I will focus on less speculative, direct consequence based arguments against the expansion of corporate criminal liability. Since I make only a relatively weak claim that CI's approach to theorising corporate criminal liability is promising and worthy of further study and analysis, this relatively narrow discussion should suffice. In evaluating these direct consequence based arguments, I will, where appropriate, consider what consequences the criminal law countenances when convicting natural persons. This is relevant because corporate convictions trade on their similarity to convictions of natural persons. Therefore, similar standards should apply when deciding which effects of a conviction we are willing to countenance. This would also improve the criminal law's internal consistency. After all, the criminal law should not, absent good reason, apply double standards in its treatment of natural and corporate persons.

In what follows, I survey the main direct consequence based objections to expanding corporate criminal liability, and demonstrate that they do not convince.

\section{Effects on stakeholders}

It is often suggested that convicting a company unfairly harms innocent shareholders who see their share prices drop, innocent workers who suffer if the company's viability declines, and innocent customers onto whom the costs of criminal fines are passed..$^{93}$ Consequently, we should refrain from increasing the incidence of such unfair harms.

Several responses suggest themselves. For one thing, shareholders, workers, and customers usually share the benefits ${ }^{94}$ (increased profitability, lower prices) derived by a company through undetected criminal wrongdoing. Therefore, it seems fair that they should also share

\footnotetext{
93 Ormerod and Laird, Smith, Hogan, p. 261; Sullivan, "Attribution of Culpability", p. 523; Wells, Corporations and Criminal Liability, p. 35.

94 Buell, "Entity Criminal Liability", pp. 496, 523.
} 
the detriments of those actions. Doing so would make the price of goods or services produced better represent the true cost of production, by forcing companies to internalise the social cost of corporate crime, rather than pass it on either to the public generally, or some segment thereof. ${ }^{95}$

Furthermore, corporate criminal liability is not imposed on shareholders or customers themselves. Its effects on these stakeholders is indirect, and therefore more dilute. Little stigma attaches to persons by virtue of being small shareholders, customers, or incidental employees of a convicted company, when compared with the stigma that attaches to persons convicted in their own right. ${ }^{96}$

But more importantly, if we feel that these indirect consequences for shareholders, employees, and customers are too harsh, consider that when a natural person is convicted, people who depend on or are associated with her also bear similar indirect consequences. When the major breadwinner of a family is imprisoned, or struggles to secure employment due to a conviction, it is myopic to think that the family is not severely affected. The conviction may also affect the convict's employees, employers and customers. These factors occasionally mitigate a sentence, but they are irrelevant when determining the law's applicability to the defendant. ${ }^{97}$ It would be absurd to make entire tracts of criminal law inapplicable to major breadwinners of a family because of how harshly convicting such persons would affect the people dependent on them. What's good for the goose must, absent compelling reasons to think otherwise, be good for the gander.

\section{Employees tainted by convictions}

Concern is sometimes expressed that when a corporation is convicted, any natural persons whose conduct has come in for criticism are likely to be tainted by their association with the conviction, and they might therefore face disciplinary, employment, and pension-right consequences. ${ }^{98}$

B. Fisse, "Sentencing Options Against Corporations" (1990) 1 Crim. L.F. 211, 212; Simester et.al., Simester and Sullivan, p. 293; Wells, Corporations and Criminal Liability, pp. 35-36.

96 Buell, "Entity Criminal Liability", pp. 502, 522.

97 Ibid., pp. 522-23.

98 Sullivan, "Attribution of Culpability", pp. 528-29; See also Gobert and Punch, Rethinking Corporate Crime, p. 66. 
This objection is unconvincing. Employees whose conduct brings the company into disrepute may face disciplinary, employment, and pension-right consequences regardless of corporate criminal consequences. Moreover, one struggles to sympathise with individuals who, by their conduct, implicate the company in criminality, for any indirect reputational damage they might suffer, ${ }^{99}$ and there is little evidence to suggest that this supposed taint is perceived outside certain rarefied business circles.

\section{Liability for criminality of low-level employees}

Sullivan objects that it would be unfair to let low-level employees expose companies to criminal liability. ${ }^{100}$ This objection is backed only by an appeal to intuition, and Sullivan does not explain the sense in which he thinks this is unfair, However, he may have meant that letting low-level employees expose companies to criminal liability would be:

a. unfair because a well-run company, whose directors take care to ensure compliance with the law, ought not to be criminally liable for incidents attributable solely to the misconduct of one of its employees; or

b. unfair, as between larger and smaller companies, because larger companies, having more employees, would be more exposed to criminal liability through their employees than smaller companies, or

c. unfair, as between companies on the one hand and natural persons on the other, because it makes companies more likely than natural persons to face criminal liability.

Each development of the objection is convincing.

The first is question-begging. It is only appealing if we assume that the company is someone other than the misbehaving employee. But identification is not an argument about the fairness of attributing the conduct and mental states of one agent (the employee) to another (the company). It is an argument about who the latter agent is. And if the entity of latter agent includes the employee, then the question of whether it is fair to blame the company for the misconduct of the employee does not arise.

As for the second development of the objection, even if it were true that larger companies would be more likely to face criminal liability than smaller ones, counterbalancing

\footnotetext{
99 Buell, “Entity Criminal Liability”, p. 523.

100 Sullivan, “Attribution of Culpability”, p. 543.
} 
considerations exist. It may well be appropriate to hold the large company liable, in that, as previously argued, the company may justifiably be seen as the true culprit. For instance, in Sullivan's insurance misselling example, ${ }^{101}$ the public perception is that the company cheats the customer, and so it should be liable. After all, the company's policies push employees to stretch ethical boundaries in pursuing targets, profits, promotions, and bonuses.

Additionally, when CI attributes wrongdoing by low-level employees to the company, the offences involved will often be fairly minor and carry limited financial penalties. Conceivably, switching to CI might necessitate companies setting aside additional resources for preventive measures like training and oversight of employees, and for meeting any potential criminal liability. But larger companies, which face greater exposure to criminal liability under CI, are also more likely to have the resources to make such arrangements. Doing so would of course add to the costs of doing business, but these costs must be balanced against hidden payoffs to the company (the criminal and civil liability, and reputational damage, averted by preventive measures), and to society (in reducing criminal activity).

And finally, if Sullivan's objection relates to the criminal law being unfair to corporations vis-à-vis natural persons, then consider that the harshest punishments - imprisonment and (where available) death - are conceptually inapplicable to corporations. ${ }^{102}$ The stigma of a criminal conviction however, does translate to corporations, and may well affect the company's reputation and ability to access funding or contract opportunities. Indeed, one would hope so, so that the threat of conviction might deter. These consequences, though unwelcome, may nevertheless be justly visited upon companies that offend.

Of course, companies that actively discourage criminality may feel hard done by if one-off incidents lead to convictions. But often what is truly a one-off is getting caught. Moreover, prosecutors enjoy significant discretion in making prosecutorial decisions, and may use it forego prosecuting truly one-off cases. Many seriously stigmatising offences applicable to natural persons are set out in over-inclusive terms and we trust prosecutors to exercise their discretion in pursuing only appropriate cases. ${ }^{103} \mathrm{We}$ should be equally willing to trust

\footnotetext{
101 Ibid., p. 519.

102 Note 85 above.

${ }^{103}$ See in this connection R.A. Duff, The Realm of Criminal Law (Oxford 2018), 64-65.
} 
prosecutorial discretion for corporate defendants. ${ }^{104}$ Indeed history shows that minor corporate offences are rarely prosecuted. ${ }^{105}$

One might also add that convictions have reputational and access-limiting consequences for natural persons too. Arguably, they are affected more severely - prior convictions must be disclosed when applying for jobs, university places, and visas. While many (including me) feel that this is too harsh, there is little appetite for radical change. Just as natural persons have to work hard to rehabilitate a reputation damaged by a conviction, so too should corporate persons. In some ways, corporations have it better than natural persons - they can dissolve and be reincarnated under different names. But even if a company derives too much value from an existing identity for this to be viable, it can engage in corporate social responsibility activities to rehabilitate its reputation, or to generate evidence of what may be termed good corporate character, which may helpfully be cited in mitigation.

\section{Unsuitability of punishments}

Occasionally, CI would facilitate a corporate conviction for crimes punishable only with imprisonment. This would be rare - rarely would an employee be acting in the course of her employment while doing something so improper. Even so, since companies cannot be imprisoned, does this suggest that CI is over-inclusive and flawed?

Clearly not. Of course we must be more innovative in devising appropriate punishments for corporations. ${ }^{106}$ Since different factors are relevant when considering how to punish corporations and natural persons, ${ }^{107}$ they may plausibly be subjected to different punishments

104 Admittedly, this prosecutorial discretion may well be exercised to effectively maintain the status quo, as has happened in many US jurisdictions. See Garrett note 57, Too Big to Jail, pp. 20-36. I cannot address that worry in detail here, but two possible responses present themselves. First, one might say that in exercising prosecutorial discretion too, the same standards as apply to natural persons should ordinarily apply to companies, with deviations therefrom needing justification. Second, one might find value in subjecting corporations to the discretion of the prosecutor, because this helps the criminal law achieve its deterrent objectives.

105 Law. Com. C.P. No. 195, paras. 1.25-1.32; Wells, Corporations and Criminal Liability, p. 20.

106 Wells, Corporations and Criminal Liability, pp. 31-39; Diamantis, “Corporate Criminal Minds”, pp. 2064-66.

107 Note 85 above. 
for the same offence. In any event, the inappositeness of punishments for certain offences to corporations does not imply a liberty for corporations to commit those offences. ${ }^{108}$

One may wonder whether trying companies for offences for which they cannot, in terms of the legally available options, be punished is a valuable use of judicial resources. But, not only are symbolic criminal proceedings possible, ${ }^{109}$ they may have significantly punitive effects for corporations by inflicting reputational damage and reducing access to contract and funding opportunities. ${ }^{110}$ In any event, letting the availability of appropriate punishments dictate the law's applicability to a particular defendant, and more fundamentally, the attributability of certain offences to a defendant, is letting the legal tail wag the dog. Whether we should prosecute a company for offences only punishable by imprisonment should be a question of expedience, not one of law. ${ }^{111}$

\section{Corporations victimised by employees}

CI suggests that the acts of employees, acting within the course of employment, but victimising the company itself, ought also to be attributed to the company. Surely that cannot be appropriate?

Consider Standard Oil Co of Texas v US. ${ }^{112}$ Corrupt corporate employees falsified legally mandated records to show that an external supplier was selling oil to the company, when in fact it was being produced in the company's own wells. The company paid the putatively external supplier for the oil, and corrupt employees received a kickback. When prosecuted for failing to keep proper records, and for transporting contraband oil, the employees' acts were not attributed to the company, and the company was acquitted. Sullivan explains this ruling by arguing that "a crime perpetrated in the course of employment should not inculpate the company where the company... is itself the sole victim of the offence". ${ }^{113}$

${ }^{108}$ Occasionally, we might glean a legislative intent to disapply an offence to corporations from the type of punishment prescribed. But this would be rare, especially as regards offences that existed before serious thought was given to the possibility of convicting corporations.

${ }^{109}$ E.g. R. v Bentley (Deceased) [2001] 1 Cr. App. R. 21.

110 Buell, "Entity Criminal Liability", pp. 487-88.

${ }^{111}$ Gobert and Punch, Rethinking Corporate Crime, ch. 7; M. Jefferson, "Corporate Criminal Liability: The Problem of Sanctions" (2001) 65 J. Crim. L. 235.

112307 F.2D. 120 (1962).

${ }^{113}$ Sullivan, "Attribution of Culpability", p. 543. 
Although I share Sullivan's intuition in favour of the outcome, the ruling in Standard Oil does not support Sullivan's conclusion. In Standard Oil, the conduct and intent of the corrupt employees was held not to be attributable to the company because they were not motivated by the interests of the company. ${ }^{114}$ This has nothing to do with the company being the sole victim of the employees' crimes. Indeed, if Sullivan's proposal were applied to Standard Oil, the case would have been decided differently, since the criminal offences therein related to state interests in managing oil production. ${ }^{115}$

A better way of avoiding a corporate conviction in cases in which the company is the sole victim of the offence committed "by itself" (under CI rules), is to offer the company a special defence in such cases. ${ }^{116}$ This would be entirely compatible with CI.

Interestingly, CI would obviate the need for such a special defence in relation to offences that cannot, on their own terms, be committed against oneself. For instance, if employees pilfer company property, the company could not then be prosecuted for theft, because the pilfered goods would not, vis-à-vis the company, be "property belonging to another". The employees though, would deservedly remain liable in their personal capacities.

\section{Conclusions}

I have argued that despite the plethora of problems with how the identification doctrine has hitherto been understood and applied, there is value in its approach to corporate criminal liability. This is because corporate criminal law trades on its association amongst laypersons with familiar, individual-centric conceptions of the criminal law. Corporate convictions carry the weight they do because they call to mind the stigma associated with convictions directed at natural persons. The identification doctrine reinforces this association by conceiving of a company anthropomorphically, and thus demonstrating to the general public the close parallel between the criminal law as applied to individuals, and to corporations. However, it is imperfect, and so I consider whether CI would improve it.

A survey of the outcomes generated by CI suggests that it might correct or ameliorate many of the concerns associated with extant models of identification, while potentially boosting the sociological legitimacy of corporate criminal law. This would come at the (arguable) cost of

\footnotetext{
114 Standard Oil 307 F.2D. 120 (1962), paras. 15, 26, 28, 29.

115 Ibid., para. 7.

116 cf. R. v Tyrrell [1894] 1 Q.B. 710. See also R. v Gnango [2011] UKSC 59, [2012] 1 A.C. 827.
} 
significantly expanding the scope of the criminal law in relation to companies. Some such expansion may be justifiable on its own terms. Some more may be counterbalanced by the fact that unlike natural persons, companies cannot be imprisoned and are potentially immortal.

Even so, one might plausibly think that this model is too severe on companies. It is instructive though to compare the harshness with which the criminal law treats natural persons and the harshness with which it would treat corporations under CI. While some worry that expanding the scope of corporate criminal liability would have extremely damaging effects on shareholders, employees, and customers, similar effects on the families, employers, employees, and customers of natural persons rarely raise an eyebrow. Again, while we may worry about the magnitude of damage a conviction does to a company's reputation, and access to commercial and funding opportunities, the same applies to natural persons, who are stigmatised by criminal convictions, and may consequently struggle to get jobs, university places, and visas. Natural persons must work hard to recover from the taint of a conviction. It hardly seems unfair to expect companies to do the same, possibly by engaging corporate social responsibility activities. Similarly, while we may be concerned that CI would expose companies, particularly large ones, to criminal liability even when, on the whole, they are only barely blameworthy, the criminal law does the same in respect of natural persons, and relies on prosecutorial discretion to keep the system operating fairly. If we are comfortable with relying so heavily on prosecutorial discretion to keep the criminal law in check in relation to natural persons, we should be willing to make the same leap of faith in relation to corporate persons.

While a much more detailed analysis is required before one can be confident that switching to CI would improve the law, I think that for the reasons surveyed, CI's approach to theorising corporate criminal liability is promising. Moreover, in challenges existing accounts of corporate criminal liability, CI brings into sharp focus the difference in the standards that apply when evaluating the harshness of the criminal law to corporations and to natural persons. I do not want to suggest that just because we countenance the criminal law's absurdly harsh treatment of natural persons, we should also be as harsh with companies. Instead, by using the comparison with corporate persons to draw attention to the criminal law's harshness to natural persons, I hope to encourage moderation across the board in the criminal law. Such moderation is perfectly compatible with CI, but how it might manifest will have to be considered elsewhere. 